DOI: $10.19195 / 0137-1134.119 .13$

\author{
ŁUKASZ ŻUKOWSKI \\ ORCID: 0000-0002-8595-3753 \\ Uniwersytet Wrocławski
}

\title{
NAJWYŻSZA RADA SĄDOWNICTWA W PORTUGALII
}

\begin{abstract}
Abstrakt: Opracowanie omawia pozycję ustrojową, skład, organizację oraz kompetencje Najwyższej Rady Sądownictwa w Portugalii. Jest to organ mający wyraźne zakotwiczenie w Konstytucji (art. 215 i 217), odpowiadający cechom południowoeuropejskiego modelu funkcjonowania rad sądownictwa. Jakkolwiek sędziowie nie mają formalnie większości w Najwyższej Radzie Sądownictwa, to w praktyce mogą ją uzyskać przy okazji podejmowania konkretnych decyzji. Niemniej w tym aspekcie rozwiązania przyjęte w Portugalii nie czynią zadość zaleceniom Komitetu Ministrów Rady Europy. Krytycznie są oceniane także w reportach innych instytucji (na przykład GRECO).
\end{abstract}

Słowa kluczowe: Konstytucja Portugalii, Najwyższa Rada Sądownictwa, status prawny, skład, kompetencje

\section{GENEZA I POZYCJA USTROJOWA NAJWYŻSZEJ RADY SĄDOWNICTWA}

Jakkolwiek każda rada sądownictwa ma wyjątkowy kształt, właściwy danej kulturze prawnej, tradycjom ustrojowym oraz doświadczeniom historycznym, to dokonując pewnych uogólnień, można wyróżnić pewne modele tego rodzaju instytucji w państwach europejskich. Najwyższa Rada Sądownictwa (Conselho Superior da Magistratura) funkcjonująca w Portugalii reprezentuje tak zwany południowoeuropejski model rad sądownictwa, charakterystyczny także dla Hiszpanii, Włoch czy Francji. Uwzględniając specyfikę rad sądownictwa w każdym z państw tego regionu Europy, można jednak stwierdzić, że są one zakorzenione w konstytucjach i pełnią istotne funkcje $\mathrm{w}$ zakresie zapewnienia niezależności sądów i niezawisłości sędziów, w tym zwłaszcza związane z procesem ich mianowania, awansu zawodowego oraz egzekwowania odpowiedzialności dyscyplinarnej ${ }^{1}$. Należy podkre-

1 W. Voermans, Councils for the Judiciary in Europe, s. 122-123, https://brill.com/view/journals/tilr/8/2/article-p121_4.xml?lang=ens. Por. też eadem, Models of Councils for the Judiciary in the European Union, [w:] Councils for the Judiciary in EU countries, June 1999, European Com- 
ślić, że wymienione cechy charakteryzują rady sądownictwa w większości państw członkowskich UE (w tym także Europy Środkowo-Wschodniej), w których rady sądownictwa są organami konstytucyjnymi ${ }^{2}$.

Zgodnie z art. 202 ust. 1 Konstytucji Republiki Portugalskiej z 2 kwietnia 1976 roku $^{3}$ sądy są organami wykonującymi suwerenną władzę, mającymi kompetencje do sprawowania wymiaru sprawiedliwości w imieniu ludu ${ }^{4}$. Przepis ten nawiązuje do art. 2 i 3 portugalskiej ustawy zasadniczej. Pierwszy wyraża zasadę demokratycznego państwa prawnego, opartego między innymi na suwerenności ludu oraz podziale i współzależności władz. W świetle art. 3 suwerenność, jedna i niepodzielna, należy do ludu, który sprawuje ją w formach przewidzianych Konstytucją (ust. 1), państwo podlega Konstytucji i opiera się na demokratycznej praworządności (ust. 2). Wykonując suwerenną władzę w zakresie sprawowania wymiaru sprawiedliwości w imieniu ludu, sądy są niezawisłe i podlegają tylko ustawie (art. 203). Konsty tucja ustanawia gwarancje niezależności sądów i niezawisłości sędziów w postaci zasady nieusuwalności i nieprzenoszalności ${ }^{5}$, nieponoszenia odpowiedzialności za swoje orzeczenia (poza wypadkami określonymi w ustawie) oraz zasady incompatibilitas ${ }^{6}$.

Ustanowienie Najwyższej Rady Sądownictwa (dalej także: NRS, Rada) w Portugalii ma swoją genezę w przejściu od systemu autorytarnego do demokratycznego w 1974 roku. Tymi doświadczeniami historycznymi należy tłumaczyć konstytucjonalizację tego organu w Konstytucji z 2 kwietnia 1976 roku (art. 217 i 218). Ostatecznie NRS rozpoczęła swoją działalność na podstawie ustawy z 31 grudnia 1976 roku (nr 926/76) 7 .

mission/TAIEX Tilburg University/Schoordijk Institute, s. 11, http://siteresources.worldbank.org/ INTLAWJUSTINST/Resources/Voermans_article.pdf (dostęp: 20.10.2019).

${ }^{2}$ G. Ambrasaitè-Balyniene, Comparative analysis on the High Councils for Judiciary in the EU member states and judicial immunity, październik 2015, s. 7, http://www.pravojustice.eu/storage/app/uploads/public/5ae/f8b/adb/5aef8badb2c7b574848064.pdf. (dostęp: 20.10.2019).

${ }^{3}$ Konstytucja Republiki Portugalskiej z 2 kwietnia 1976 r., przeł. A. Wojtyczek-Bonnand, [w:] Konstytucje państw Unii Europejskiej, red. W. Staśkiewicz, Warszawa 2011, s. 598 n.

4 Por. też T. Aquino Guimarães et al., Role conflict and role ambiguity in the work of judges: the perceptions of Portuguese judges, Rev. Adm. Pública 51, 2017, nr 6.

5 Zgodnie z art. 216 ust. 1 Konstytucji sędziowie są nieusuwalni i nie mogą być przenoszeni, zawieszani, przenoszeni w stan spoczynku lub odwoływani, z wyjątkiem przypadków przewidzianych w ustawie.

6 W myśl art. 216 ust. 1 Konstytucji sędziowie czynni zawodowo nie mogą sprawować żadnej innej funkcji publicznej lub prywatnej, z wyjątkiem działalności dydaktycznej lub naukowej w dziedzinie prawa, wykonywanej bez wynagrodzenia, na zasadach określonych w ustawie (ust. 3). Sędziom czynnym zawodowo nie można powierzać wykonywania zadań służbowych niezwiązanych z działalnością sądów bez zezwolenia właściwej rady najwyższej (ust. 4). Ustawa może ustanowić inne zakazy łączenia stanowisk z funkcją sędziego (ust. 5).

7 Akty prawne regulujące status Najwyższej Rady Sądownictwa — ustawa 21/85 z 30 lipca, znowelizowana ustawą 10/94 z 5 maja i ustawą 143/99 z 31 sierpnia; ustawa 36/2007 z 14 sierpnia; ustawa 52/2008 z 28 sierpnia, znowelizowana ustawą 102/2009 z 11 września; ustawa 115/2009 z 12 października; dekret 295/2009 z 13 października; ustawa 3-B/2010 z 28 kwietnia; ustawa 


\section{SKŁAD I ORGANIZACJA NAJWYŻSZEJ RADY SĄDOWNICTWA}

Skład Najwyższej Rady Sądownictwa określa art. 218 Konstytucji. Wśród siedemnastu jej członków dwóch wyznacza Prezydent Republiki, siedmiu jest wybieranych przez Zgromadzenie Republiki, a siedmiu przez sędziów spośród ich grona, zgodnie z zasadą proporcjonalności. Jeden członek Rady pełni funkcję z urzędu - przewodniczący Najwyższego Trybunału Sprawiedliwości ${ }^{8}$, który również z urzędu przewodniczy Najwyższej Radzie Sądownictwa. Wiceprzewodniczącym jest jeden z członków Rady będących sędziami, przy czym tylko jeden z nich musi być sędzią Sądu Najwyższego i ten właśnie zostaje mianowany wiceprzewodniczącym. Podobnie jak w Hiszpanii prokuratura nie jest częścią portugalskiej Najwyższej Rady Sądownictwa9 .

W odniesieniu zatem do osoby przewodniczącego i wiceprzewodniczącego rozwiązania przyjęte w Portugalii czynią zadość zaleceniom Rady Konsultacyjnej Europejskich Sędziów (dalej: CCJE) ${ }^{10}$, podkreślającym, że powinna to być osoba bezstronna oraz niemająca związków z partiami politycznymi. Akceptuje ona zatem dwa modele wyłaniania przewodniczącego rady: albo przez nią samą spośród sędziów, albo powierzenie tej funkcji — jak ma to miejsce w Portugalii — prezesowi sądu najwyższego ex officio ${ }^{11}$.

Wybór sędziów wchodzących w skład NRS odbywa się w wyborach powszechnych, w tajnym głosowaniu, z uwzględnieniem konstytucyjnego wymogu proporcjonalnej reprezentacji ${ }^{12}$. Nadzór nad prawidłowością procedury wyborczej sprawuje Komisja Wyborcza (funkcjonująca w siedzibie NRS), na której czele stoi przewodniczący Najwyższego Trybunału Sprawiedliwości ${ }^{13}$, będący z urzędu jak zaznaczono - przewodniczącym NRS.

W składzie Najwyższej Rady Sądownictwa sędziowie nie stanowią większości (8 sędziów na 17 członków). Niemniej na podkreślenie zasługuje — jak wskazano - że zarówno przewodniczącym (z urzędu), jak i wiceprzewodniczącym jest sędzia Sądu Najwyższego, odpowiedzialny za zarządzanie Radą i zatrudniony w niej na pełnym etacie. Dotyczy to również wszystkich pozostałych sędziów

40/2010 z 3 września; ustawa 43/2010 z 3 września; ustawa 46/2011 z 24 czerwca, por. Conselho Superior da Magistratura, http://www.csm.org.pt (dostęp: 20.10.2019).

8 W myśl art. 210 Konstytucji Najwyższy Trybunał Sprawiedliwości jest najwyższym organem w hierarchii sądów powszechnych, a jego przewodniczący jest wybierany przez sędziów wchodzących w skład Trybunału.

9 W. Voermans, Councils for the Judiciary in Europe..., s. 123.

${ }^{10}$ Consultative Council of European Judges (CCJE), https://www.coe.int/en/web/ccje (dostęp: 20.10.2019).

11 G. Ambrasaitė-Balynienè, op. cit., s. 12-13.

12 Por. A. Trubalski, Portugalia, [w:] Rady Sadownictwa w państwach Unii Europejskiej. Przegląd rozwiązań, red. A. Pogłódek, Warszawa 2019, s. 183.

13 Szczegółowo procedurę wyborczą omawia A. Trubalski, ibidem. 
zasiadających w Radzie poza jej przewodniczącym ${ }^{14}$. Jakkolwiek o charakterze zatrudnienia decyduje członek Rady, to przyjęło się, że członkowie-sędziowie sprawują tę funkcję pełnoetatowo, członkowie pozasądowi zaś zatrudnieni są w Radzie $\mathrm{w}$ niepełnym wymiarze godzin ${ }^{15}$.

Problem mniejszości sędziów (czy też niewielkiej większości osób niebędących sędziami) w składzie portugalskiej Najwyższej Rady Sądownictwa został dostrzeżony w rekomendacjach skierowanych pod adresem Portugalii w raporcie GRECO $^{16}$, wskazujących, że rola rad sądownictwa jako gwarantów niezależności sędziów i sądownictwa jest wzmocniona, w szczególności poprzez zapewnienie w prawie krajowym, że nie mniej niż połowa ich członków jest sędziami wybieranymi przez sędziów spośród ich grona (pkt VI). We wskazanym raporcie odwołano się także do zalecenia Komitetu Ministrów Rady Europy ${ }^{17}$, w którym podkreślono, że sędziowie wybrani przez sędziów powinni tworzyć nie mniej niż połowę członków rady sądownictwa. Tego wymogu rozwiązania przyjęte w Portugalii zatem nie spełniają, choć możliwość zakwestionowania decyzji Rady przed sądem wydaje się zapewniać odpowiedni środek odwoławczy ${ }^{18}$. Decyzje podjęte przez zgromadzenie plenarne Rady w niektórych sprawach, głównie dotyczących oceny sędziów, ich awansu lub środków dyscyplinarnych, mogą zostać ponownie zbadane przez Sąd Najwyższy ${ }^{19}$.

Ponadto w przywołanym raporcie GRECO podkreślono, że sędziowie portugalscy korzystają ze wskazanych konstytucyjnych gwarancji niezawisłości, związania wyłącznie konstytucją i ustawami, niepodlegania instrukcjom wykraczającym poza obowiązek przestrzegania orzeczeń sądów wyższych instancji, nieusuwalno-

14 Association of Polish Judges „Iustitia” 's response to the A Supplement to the White Paper on the Reform of the Polish Judiciary dated March 22, 2018, prepared on the basis of information collected from EU member states judges, https://www.iustitia.pl/79-informacje/2201-association-of-polish-judges-iustitia-s-response-to-the-a-supplement-to-the-white-paper-on-the-reform-of-the-polish-judiciary-dated-march-22-2018-prepared-on-the-basis-of-information-collected-from-eu-member-states-judges (dostęp: 20.10.2019).

15 Conselho Superior da Magistratura, http://www.csm.org.pt. Por. G. Ambrasaite-Balynienè, op. cit., s. 13.

${ }^{16}$ Fourth Evaluation Rund. Corruption prevention in respect of members of parliament, judges and prosecutors, Evaluation Report. Portugal. Adopted by GRECO AT its 70th Plenary Meeting (Strasbourg, 30 November-4 December 2015), Adoption: 4 December 2015 Public Publication: 10 February 2016 Greco Eval IV Rep (2015) 5E, s. 58, https://rm.coe.int/16806c7c10. Zwrócono na to uwagę w Odpowiedzi Stowarzyszenia Sędziów Polskich „Iustita” z 6 kwietnia 2018 roku na Suplement do Białej Księgi w sprawie reformy polskiego wymiaru sprawiedliwości z 22 marca 2018 roku, opracowanej na podstawie informacji otrzymanych od sędziów z krajów członkowskich UE, https://www.iustitia.pl/79-informacje/2200-odpowiedz-stowarzyszenia-sedziow-polskich-iustitia-na-suplement-do-bialej-ksiegi-w-sprawie-reform-polskiego-wymiaru-sprawiedliwosci-z-dnia-22-marca-2018-r-opracowana-na-podstawie-informacji-zebranych-od-sedziow-z-krajow-czlonkowskich-ue (dostęp: 20.10.2019).

17 Zalecenie Komitetu Ministrów Rady Europy CM/Rec(2010) 12.

18 Por. Odpowiedź Stowarzyszenia Sędziów Polskich „Iustita”...

19 Conselho Superior da Magistratura... 
ści i nieprzenoszalności poza wypadkami przewidzianymi w ustawie. Co również istotne, w myśl art. 218 ust. 2 Konstytucji wszyscy członkowie Najwyższej Rady Sądownictwa korzystają z zasad dotyczących wskazanych wyżej gwarancji, które Konstytucja Portugalii ustanawia dla sędziów.

Zgodnie z opinią CCJE członkowie rad sądownictwa niebędący sędziami nie powinni być mianowani przez organ władzy wykonawczej. CCJE rekomenduje system, w którym mianowanie osób niebędących sędziami powierza się organom niepolitycznym, niemniej w dużej części państw członkowskich UE wybór członków rad niebędących sędziami należy do parlamentu lub — jak w wypadku portugalskiej Najwyższej Rady Sądownictwa - prezydenta i parlamentu ${ }^{20}$. Zgodnie z zaleceniami CCJE wybór członków rady sądownictwa niebędących sędziami przez parlament powinien następować kwalifikowaną większością głosów spośród osób niebędących parlamentarzystami w sposób zapewniający różnorodną reprezentację społeczeństwa w składzie rady sądownictwa ${ }^{21}$. Wprawdzie w Portugalii ukształtowała się pewna tradycja, że Prezydent Republiki mianował emerytowanych sędziów lub byłych prezesów Trybunału Konstytucyjnego na członków Rady $^{22}$, co powodowało, że faktycznie w składzie Najwyższej Rady Sądownictwa większość mieli sędziowie. Jednak praktyka ta nie ma podstawy prawnej, a w ostatnim czasie można zauważyć odejście od niej²3.

Należy też zwrócić uwagę, że art. 218 ust. 3 Konstytucji portugalskiej dopuszcza, by ustawa przewidywała, że członkami Najwyższej Rady Sądownictwa będą urzędnicy wymiaru sprawiedliwości, wybrani ze swojego grona, z prawem udziału w dyskusji i głosowaniu, ale tylko w sprawach dotyczących oceny osiągnięć zawodowych i prowadzenia postępowania dyscyplinarnego wobec urzędników wymiaru sprawiedliwości.

Kadencja członków Najwyższej Rady Sądownictwa jest taka sama jak organu, który dokonał mianowania, mianowicie 5 lat dla osób mianowanych przez Prezydenta Republiki, 4 lata dla osób wybranych przez parlament, 3 lata dla członków wybranych z grona sędziów. Sędzia może być ponownie wybrany do składu tylko jeden raz. Takich ograniczeń nie ma natomiast w wypadku pozostałych członków ${ }^{24}$.

Pracami Rady kieruje przewodniczący oraz wiceprzewodniący, do którego należy zastępowanie przewodniczącego w razie jego nieobecności lub przeszkód w pełnieniu funkcji oraz wykonywanie innych powierzonych mu zadań. Wiceprzewodniczący jest wybierany w bezpośrednich, powszechnych wyborach, w głosowaniu tajnym wszystkich sędziów ${ }^{25}$.

\footnotetext{
20 G. Ambrasaitè-Balynienè, op. cit., s. 12.

21 Ibidem.

22 Por. Odpowiedź Stowarzyszenia Sędziów Polskich „Iustita”...

23 Ibidem.

24 Conselho Superior da Magistratura... Por. G. Ambrasaitė-Balynienè, op. cit., s. 9.

25 Conselho Superior da Magistratura...
} 
Strukturę organizacyjną NRS tworzą: Rada Plenarna, Stała Rada, Rada Dyrektorów oraz Zarząd. Radę Plenarną tworzą wszyscy członkowie NRS. Natomiast w skład Rady Stałej wchodzą: przewodniczący oraz wiceprzewodniczący NRS, członkowie wybrani przez sędziów, jeden członek wyznaczony przez Prezydenta Republiki oraz czterech członków spośród siedmiu wybranych przez Zgromadzenie Republiki ${ }^{26}$. Zarząd składa się z przewodniczącego i wiceprzewodniczącego NRS, sekretarza (wybranego w głosowaniu na posiedzeniu plenarnym spośród sędziów), trzech członków wybieranych corocznie przez Radę Plenarną oraz dyrektora do spraw administracyjnych i finansowych ${ }^{27}$.

\section{KOMPETENCJE NAJWYŻSZEJ RADY SĄDOWNICTWA}

Najważniejsze kompetencje Najwyższej Rady Sądownictwa dotyczące kariery sędziowskiej określa art. 217 Konstytucji. W jego świetle do kompetencji Rady należy: powoływanie, przyznawanie stanowisk, przenoszenie i awansowanie sędziów sądów powszechnych oraz przeprowadzanie postępowania dyscyplinarnego na zasadach określonych w ustawie (ust. 1). Natomiast powoływanie, przyznawanie stanowisk, przenoszenie i awansowanie sędziów sądów administracyjnych i podatkowych oraz przeprowadzanie postępowania dyscyplinarnego na zasadach określonych w ustawie należy do kompetencji właściwej rady najwyższej (ust. 2). Ponadto, zgodnie z ust. 3 tego przepisu, ustawa określa zasady postępowania i kompetencje w zakresie przyznawania stanowisk, przenoszenia i awansowania oraz przeprowadzania postępowania dyscyplinarnego wobec sędziów pozostałych sądów, z zachowaniem gwarancji przewidzianych w Konstytucji.

Należy zauważyć, że CCJE opowiada się za nominacjami sądowymi dokonanymi przez samą radę sądownictwa, jak ma to miejsce w Portugalii (podobnie we Włoszech i Hiszpanii). W tym zakresie kompetencje nominacyjne Najwyższej Rady Sądownictwa wyróżniają się na tle większości państw członkowskich UE, w których mianowanie sędziów jest dokonywane na podstawie aktu głowy państwa lub rzadziej parlamentu ${ }^{28}$.

Konstytucja w art. 215 określa zasady i warunki powoływania sędziów, niemniej w wypadku sędziów sądów powszechnych pierwszej instancji odsyła w pełnym zakresie do regulacji ustawowej. Natomiast sędziowie sądów powszechnych drugiej instancji są powoływani spośród sędziów sądów pierwszej instancji przede wszystkim na podstawie kryterium osiągnięć, w konkursie, w którym uwzględnia się przebieg pracy zawodowej (ust. 3). Z kolei powołanie do Najwyższego Trybunału Sprawiedliwości następuje w konkursie, w którym uwzględnia się przebieg

\footnotetext{
26 Por. A. Trubalski, op. cit., s. 184.

27 Ibidem.

28 G. Ambrasaitè-Balynienè, op. cit., s. 15-16.
} 
pracy zawodowej, otwartym dla sędziów, prokuratorów oraz innych zasłużonych prawników, na zasadach określonych w ustawie (ust. 4).

W zakresie szkoleń sędziów odpowiedzialność za ich organizację spoczywa na Centrum Studiów Sądowych pod patronatem Ministerstwa Sprawiedliwości. Niemniej NRS ma swojego członka w Radzie Pedagogicznej i może również organizować szkolenia. Pomimo że formalnie nie obowiązuje żaden Kodeks Etyki Sędziowskiej, do kompetencji Rady należy troska o promowanie zasad etyki sędziowskiej. Zasady etyki sędziowskiej określa Statut Sądów ${ }^{29}$.

Do kompetencji NRS należy też prowadzenie postępowań dyscyplinarnych wobec sędziów. Ponadto ma ona kompetencje doradcze, w tym uprawnienie do opiniowania projektów aktów prawnych dotyczących sądownictwa i statusu sędziów oraz do analizowania i proponowania Ministerstwu Sprawiedliwości rozwiązań legislacyjnych w celu poprawy skuteczności sądownictwa ${ }^{30}$.

NRS ma autonomię finansową oraz własny budżet, stanowiący część budżetu państwa. Jest on zatwierdzany przez Zgromadzenie Republiki na wniosek Rady, przesyłany każdego roku do końca sierpnia. Budżet Rady obejmuje: centrum dokumentacji sądowej, inspektorat sądowy i wydatki samej Rady. Natomiast wydatki na szkolenia sędziów są objęte budżetem Ministerstwa Sprawiedliwości ${ }^{31}$.

Kompetencje NRS podzielone zostały między jej organy. Do Rady Plenarnej NRS należy: wykonywanie najważniejszych kompetencji w zakresie mianowania, awansowania i oceny pracy sędziów, podejmowanie czynności dyscyplinarnych wobec sędziów, wydawanie opinii na temat aktów prawnych dotyczących organizacji sądów i statusu sędziów, a także analizowanie i przedstawianie Ministrowi Sprawiedliwości wspomnianych propozycji legislacyjnych służących poprawie skuteczności i funkcjonowania instytucji sądowych, mianowanie przewodniczącego sądu okręgowego, a także rozpatrywanie i rozstrzyganie skarg dotyczących działań podejmowanych przez Stałą Radę, Przewodniczącego, Wiceprzewodniczącego lub członków NRS ${ }^{32}$.

Z kolei do właściwości Stałej Rady należą sprawy nieprzekazane Radzie Plenarnej, z wyjątkiem kompetencji dotyczących sądów wyższych instancji i ich sędziów. Są to kompetencje w zakresie mianowania, awansowania i oceny kwalifikacji zawodowych sędziów, podejmowania czynności dyscyplinarnych wobec sędziów, sporządzania rocznego planu inspekcji, dokonywania zmian w przydziale spraw sądom w celu zapewnienia równomiernego obciążenia sądów, podejmowania działań na rzecz eliminowania przewlekłości postępowań sądowych czy przedstawiania Ministrowi Sprawiedliwości odpowiednich środków w celu unikania nadmiernego obciążania sędziów sprawami ${ }^{33}$.

\footnotetext{
29 Conselho Superior da Magistratura...

30 G. Ambrasaitė-Balynienè, op. cit., s. 22-23.

31 Conselho Superior da Magistratura...

32 Ibidem.

33 Ibidem.
} 
Rada Dyrektorów jest natomiast organem właściwym w sprawach finansowych $^{34}$. Do jej zadań należy: opiniowanie rocznych planów działań i sprawozdań $\mathrm{z}$ ich realizacji, opiniowanie projektu rocznego budżetu i jego poprawek, przedkładanie go do zatwierdzenia przez Najwyższą Radę Sądownictwa, nadzorowanie wydatków oraz organizacja rachunkowości ${ }^{35}$.

Przewodniczący Najwyższej Rady Sądownictwa reprezentuje ją na zewnątrz, wykonuje funkcje przekazane mu przez NRS z uprawnieniem do ich delegowania na rzecz wiceprzewodniczącego, kieruje i koordynuje służbami inspekcyjnymi, a także wykonuje inne funkcje powierzone mu w ustawach ${ }^{36}$.

\title{
HIGH COUNCIL FOR THE JUDICIARY IN PORTUGAL
}

\author{
Summary
}

The study discusses the political position, composition, organisation and competence of the High Council for the Judiciary in Portugal. It is an office clearly supported by the constitution (Articles 215 and 217), demonstrating the features of the southern European model of the functioning of judicial councils in Europe. Although judges do not formally have a majority in the High Council for the Judiciary, they can in practice obtain it when making specific decisions. However, in this aspect, the solutions adopted in Portugal do not follow the recommendations of the Committee of Ministers of the Council of Europe. They are also critically assessed in reports of other institutions (e.g. GRECO).

Keywords: Constitution of Portugal, High Council for the Judiciary, legal status, composition, competences

\section{BIBLIOGRAFIA}

Aquino Guimarães T., Oliveira Gomes A., Ribeiro Correia P.M.A., Oliveira I, Piazentin T., Role conflict and role ambiguity in the work of judges: the perceptions of Portuguese judges, Rev. Adm. Pública 51, 2017, nr 6.

Konstytucja Republiki Portugalskiej z 2 kwietnia 1976 r., przeł. A. Wojtyczek-Bonnand, [w:] Konstytucje państw Unii Europejskiej, red. W. Staśkiewicz, Warszawa 2011.

Trubalski A., Portugalia, [w:] Rady Sądownictwa w państwach Unii Europejskiej. Przeglad rozwiązań, red. A. Pogłódek, Warszawa 2019.

34 Por. art. 10 ust. 1 ustawy nr 36/2007 z 14 sierpnia.

35 Conselho Superior da Magistratura...

36 Ibidem. 